Vol. 8 (4): 691-696 (2018)

\title{
CHILD MALTREATMENT IN EUROPEAN REGION AND IN ALBANIA
}

\author{
Rovena Daja $^{1 *}$, Rudina Cumashi ${ }^{1}$, Gentiana Qirjako ${ }^{1}$ \\ ${ }^{1 *}$ Institute of Public Health, Tirana-Albania \\ *Correspondent author: Rovena Daja, email: rovenadaja@yahoo.com;
}

Received May, 2018; Accepted June, 2018; Published July, 2018;

DOI: https://doi.org/10.31407/ijees8406

UOI license: http://u-o-i.org/1.01/ijees/39865196

\begin{abstract}
Child maltreatment is a problem of epidemic proportions in the European Region and United States. Given the numbers of children affected by child maltreatment and the dire consequences that can develop, prompt identification of child maltreatment is crucial. This is a systematic review conducted by searching databases for relevant literature assessing the childhood maltreatment. Child maltreatment leads to the premature death of 852 children under 15 years in the European Region every year. Not all deaths from maltreatment are properly recorded and this figure is likely to be an underestimate. Data show inequalities in the Region with higher death rates in the east, though trends seem to be declining overall. Deaths, however, are only the tip of the iceberg: much abuse may not come to the attention of child protection services. National policies and practices on maltreatment vary between countries, making it difficult to take a regional view. Vital registration and official statistics need to be improved to provide a better picture of the scale of the problem at country level. Multidisciplinary approaches to cases, with teams using reliable and valid investigative methods, and periodic surveys to detect hidden maltreatment in the community would contribute greatly to this.
\end{abstract}

Key words: maltreatment, abuse, neglect, violence. 